\title{
Online Learning Development of Interactive Multimedia based Geographic Information Systems
}

\author{
Ni Nyoman Supuwiningsih \\ Department of Computer System \\ STIKOM Bali, Indonesia
}

\author{
I. Wayan Jepriana \\ Department of Information System \\ STIKOM Bali, Indonesia
}

\begin{abstract}
The learning paradigm at this time has changed from teachercentered learning to student-centered learning. In this digital era, all data and information are spread in all parts of the world, so that everyone can easily access all the desired information. All information is very much in the virtual world so information filters are needed to get useful and positive information. At this time learning is very likely to do online / cyberspace / internet using online learning applications. Many factors of online learning development are students / students spread so that the constraints in time and resources in traveling, students / students have a busy work, students / students have difficulty in communication in real time, students / students have limitations / constraints when participate in face-to-face classes. Based on these factors, it is necessary to have online learning facilities in interactive multimedia-based learning, especially learning Geographic Information Systems, which most students / students are very difficult to get the subject matter. This application is able to bridge between students and educators that are not limited to space and time. This study consists of learning modules of Geographic Information Systems which are combined in the application of online learning using interactive multimedia. This application is also able to facilitate online learning that can be accessed at any time as long as it is connected to the internet. The LMS (Learning Management System) built for online learning of STIKOM Bali students using moodle collaborated with Adobe software captivate multimedia.
\end{abstract}

\section{Keywords}

Online learning, LMS (Learning Management System), moodle, Geographic Information Systems

\section{INTRODUCTION}

The learning paradigm at this time has changed from teachercentered learning to student-centered learning. In this digital era, all data and information are spread in all parts of the world, so that everyone can easily access all the desired information. All information is very much in the virtual world so information filters are needed to get useful and positive information.

Many factors of online learning development are students / students spread so that the constraints in time and resources in traveling, students / students have a busy work, students / students have difficulty in communication in real time, students / students have limitations / constraints when participate in face-to-face classes [21]. Based on these factors, it is necessary to have online learning facilities in interactive multimedia-based learning, especially learning Geographic Information Systems, which most students / students are very difficult to get the subject matter. Applications that will be made are able to bridge between students and educators who are not limited to space and time. This study will be made a learning module of Geographic Information System that will be combined in the application of online learning using interactive multimedia. This application is expected to be able to facilitate online learning that can be accessed at any time as long as it is connected to the internet.

\section{LITERATURE REVIEW}

\subsection{Online Learning Concept}

The development of information technology is very rapidly developing from time to time, allowing everyone to access all the information that is spread, along with the ease of use of internet facilities that make the social media culture increasingly widespread to all circles, so that the dissemination of information is not limited to space and time. At this time information technology has reached out in the field of education, namely with the change in the learning paradigm which initially was only centered on teachers / instructors / lecturers, now the paradigm has changed to learning centered on students / students / learners using information technology known as e-Learning [12].

E-Learning / Online Learning is learning that is centered on students using electronic media or information technology / multimedia-based learning. Learning is an effort to teach students / learners or a process of interaction between learners and educators and learning resources in a learning environment, while learning is the connection of new knowledge to cognitive structures (thinking) or prior knowledge that students already have. E-learning is also defined as a set of information packages for learning (in one course) available anywhere at any time through an electronic delivery system, in the form of web-based learning, computerbased learning, virtual classroom, or digital collaboration. The information package consists of various objects and units, including tests and test kits that allow a person to test for his ability at any time. The information package can take the form of a variety of media, such as text, visual (video), audio, pictures / illustrations and others. The definition of e-learning has a broad understanding.

\subsection{Geographic Information System \\ Learning}

Geographic Information System (GIS) or Geographic Information System (GIS) consists of three terms namely system, information and geography is a set of components or interconnected elements between components / elements to achieve the goal (Prahasta, E.2005). The concept of information is the result of processing data and geography is the study of the surface of the earth. The concept of geographic information systems is a collection of interacting components in processing data so as to produce geographic information whose implementation is a digital map. Geographic information systems can also be defined as an information system that can analyze, store, update, integrate and display all forms of information related to the surface of the earth. 


\subsection{Multimedia Concept}

Multimedia consists of elements: text, images / photos, graphic art, sound, animation, and video elements digitally manipulated [17]. Multimedia is a medium for delivering / presenting computer-assisted content / information with either static visualization or animated visualization. The content in it can be in the form of words (such as narration or text on the screen) and graphics / images / tables / videos [11].

Multimedia learning (computer assisted) is a type of eLearning whose instruction / learning is delivered via a computer with learning content (text, images, graphics, audio, video, animation, etc.) stored / located on a CD-ROM or computer file.

\section{METHODS}

The flow of analysis from this study consists of several stages of activities along with their explanations as follows:

\section{Literature Study}

The first stage in research is the study of literature. Collection of journal and book references that can be used as references in research and compare existing research.

\section{Data Collection}

The second stage is collecting data related to research, namely data needed in making learning modules for Geographic Information Systems and data related to the creation of interactive multimedia applications.

\section{Making a Module}

The third stage is the making of a Geographic Information System learning module that will be used as a gradual material in each online learning meeting.

\section{Making Application}

The fourth stage is making an online learning application

\section{Implementation}

The fifth stage is combining the Geographic information system learning module with the application of online learning

\section{Making Reports}

The last stage is the creation of reports on the results of research on the development of online learning learning based on interactive multimedia geographic information systems.

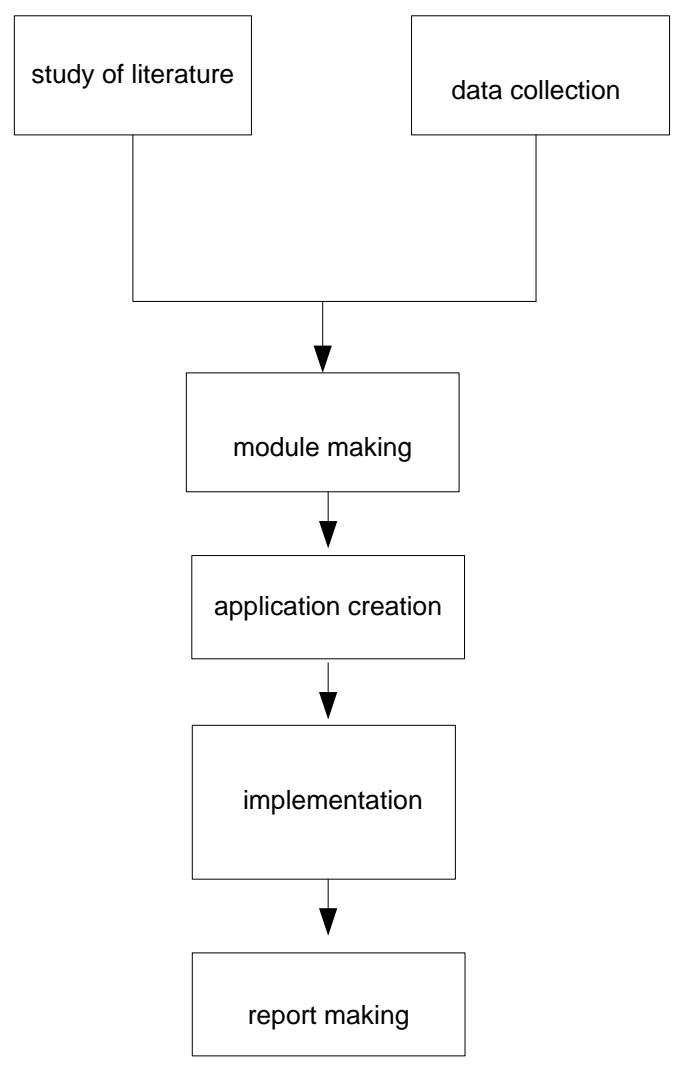

Fig 1 : Systematic research

\section{RESULT AND DISCUSSION}

\subsection{Result}

Content / material for Geographic Information System courses per meeting in accordance with RPKPS (Semester Learning Program and Activity Plans) implemented in Adobe captivate software.

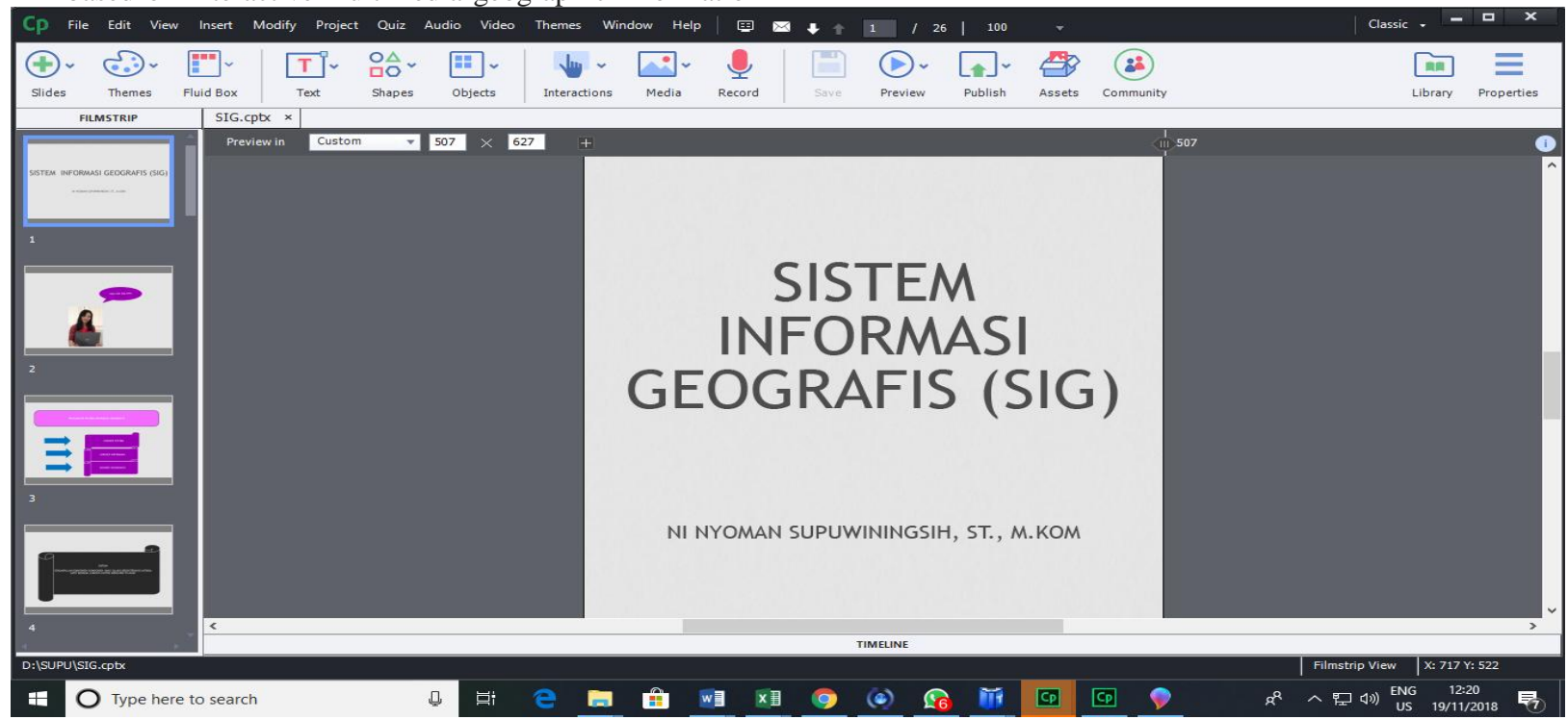

Fig 2 : The first display of multimedia adobe captivate 
The first display of the implementation of multimedia-based Geographic Information System learning into adobe captivate software can be seen in Figure 2. Learning Geographic Information Systems becomes more interesting because it is packaged using multimedia. Students can learn geographic information system courses easily because modules in applications can be studied repeatedly



Fig 3 : The second display of Adobe captivate multimedia

In Figure 3, the second display shows the implementation of GIS learning using multimedia-based adobe captivate software. Multimedia-based content can make it easier for students to learn interactively and can be repeated. Learning the Geographic Information System course module on adobe captivate software is implemented on the LMS (Learning Management System) website STMIK STIKOM Bali. The name of the website that implements online learning is

$\leftarrow \rightarrow \mathrm{C} \quad \mathrm{https} / /$ onlearn.stikom-bali.ac.id/course/view.php?id=5\#section-1

i:! Apps For quick access, place your bookmarks here on the bookmarks bar. Import bookmarks now... https://onlearn.stikom-bali.ac.id, the display of LMS (Learning Management System) STIKOM Bali can be seen in Figure 4.

LMS (Learning Management System) STIKOM Bali can provide convenience to students in studying GIS courses in particular because it can be accessed anywhere and anytime as long as it is connected to the internet.

\section{Sistem Informasi Geografis}

Rumah saya / Kursus Yang Saya Ikuti / SI-SIG

㞒 Announcements

Pertemuan I - Penganalan SIstem Informasi Geografis

11. Modul I-Pengenalan Sistem Informasi Geografis

topik 2

Fig 4 : Implementation of Adobe Captivate on the website 
Figure 4 shows the first page of the application of multimedia learning for geographic information system courses to the LMS (Learning Management System) website so that students can easily access all meeting materials because they are connected to the internet. Learning modules in geographic information systems can be studied repeatedly and packaged interactively and interestingly. LMS (Learning Management System) is a software or software for administrative purposes, documentation, reports on an activity, teaching and learning activities and online activities connected to the internet. LMS can be used in the field of education, known as E-learning, making it easier for students to access the materials provided by educators. In terms of education, it is also facilitated in sharing knowledge by uploading learning material in accordance with the topic, one of which is learning geographic information systems that are packaged interactively and attractively.

The features available in the LMS (Learning Management System) for educational institutions are as follows:

1. Management of user access rights,

2. Management of courses,
3. Management of teaching materials (resources),

4. Management of activities,

5. Value management,

6. Value display,

7. Management of e-learning visualization, so that it can be accessed with web browser

The LMS (Learning Management System) used in this study is moodle. Moodle (Modular Object-Oriented Dynamic Learning Environment) is software that is produced for internet-based learning activities and websites that use the principle of social constructionist pedagogy. Moodle is an application of the concept and mechanism of teaching and learning that utilizes information technology, known as the concept of electronic learning or e-learning. Moodle can be used freely as an open source product under the GNU license. Moodle can be installed on any computer and operating system that can run PHP and supports SQL databases. The results of the moodle display of geographic information system learning can be seen from Figure 5

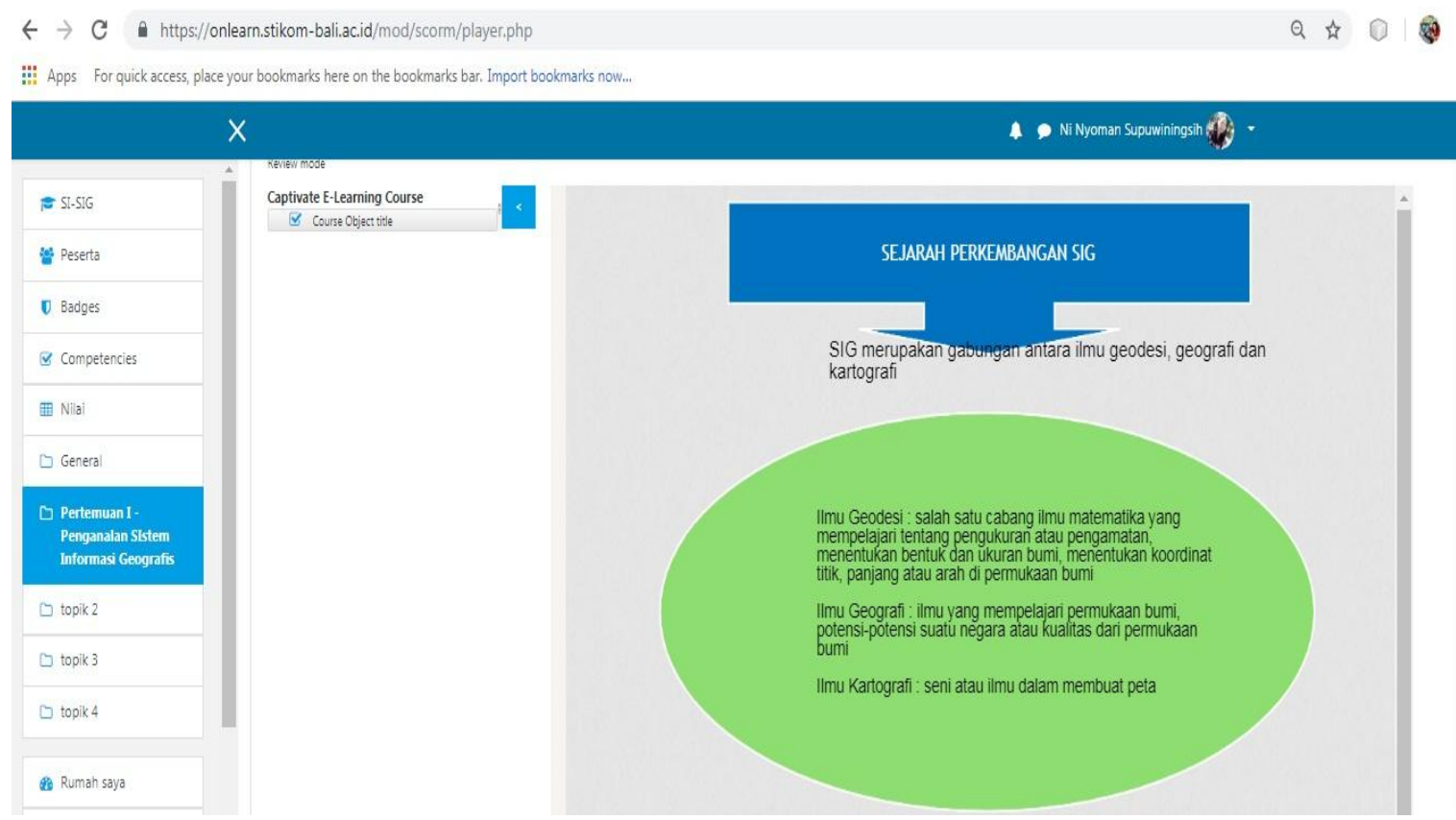

Fig 5 : Display GIS Learning into LMS

\subsection{Discussion}

Current learning methods have undergone changes from conventional learning methods to online learning methods or called online learning. Online learning built at STIKOM Bali is used to meet the needs of students in terms of learning that can be accessed wherever they are as long as it is connected to the internet. The development of multimedia online learning is very helpful for students in accessing learning materials, especially geographic information systems, which can be studied each module repeatedly until students understand. Each meeting is given an interactive multimedia learning module so that students can learn the material interactively and interestingly.

\section{CONCLUSSION AND SUGGESTIONS}

\subsection{Conclusion}

1. Development of interactive multimedia learning for online geographic information system courses has been successfully built for STMIK STIKOM Bali students

2. Multimedia learning geographic information system courses built using Adobe captivate software can be exported to moodle so that online production can be accessed by STIKOM Bali students with a website https://onlearn.stikom-bali.ac.id 


\subsection{Suggestions}

This research is expected to be further developed with Android-based to keep abreast of information technology so

\section{REFERENCES}

[1] Basri, D. H. (2015). Paradigma Baru Sistem Pembelajaran. Bandung: CV Pustaka Setia.

[2] Basri, D. H. (2015). Paradigma Baru Sistem Pembelajaran. Bandung: CV Pustaka Setia.Daryanto. (2010). Media Pembelajaran. Yogyakarta: Grava Media.

[3] Fee, K. (2009). Delivering E-Learning : A Complete Strategy for Design, Application and Assessment. Great Britain and the United States: Kogan Page .

[4] Gagne, R. (1988). Essential of Learning for Instruction (2nd.ed). Englewood Cliffs: NJ: Parentice Hall,Inc.

[5] Ghirardini, B. (2011). E-Learning Methodologies : A Guide for designing and developing e-learning course. Rome-Italy: FAO

[6] Glossary. (2001). Glossary of E-Learning Terms. LearnFrame.com.

[7] Hamalik, O. (2004). Perencanaan Pengajaran Berdasarkan Pendekatan Sistem. Jakarta: Bumi Aksara.

[8] Karen S. Ivers and Ann E. Barron. (2010). Multimedia Projects in Education. California: ABC-CLIO, LLC.

[9] Kay Lehmann and Lisa Chamberlin. (2009). Making The Move to Elearning : Putting Your Course Online. USA: A Division of Rowman \& Littlefield Publishing Group, Inc.

[10] M.Piskurich, G. (2015). Rapid Instructional Design : Learning ID Fast \& Right 3 rd Edition. Canada: John Wiley \& Son.

[11] Mayer,R.E \& Moreno, R. (2002). Animation As an Aid to Multimedia Learning. Educational Psychology Review, 87-99.

[12] Muhammad Rusli, Dadang Hermawan dan Ni Nyoman Supuwiningsih. (2017). Multimedia Pembelajaran yang Inovatif : Prinsip Dasar \& Model Pengembangan. that learning materials for other subjects can be accessed via a smartphone

Yogyakarta: Andi Offset Yogyakarta.

[13] Munir. (2001). Aplikasi Teknologi Multimedia dalam Proses Belajar Mengajar. Bandung: Alfa Beta.

[14] Ni Nyoman Supuwiningsih, Muhammad Rusli. (2017). Prediction of Decreasing Agricultural Land Based on Geographic Information System Case Study : Denpasar City. International Journal of Computer Application, 3034.

[15] Ni Nyoman Supuwiningsih, Paula Dewanti, Ni Kadek Sukerti and I Made Agus Wirahadi Putra. (2018). Forecasting of Agricultural Production Results in South Denpasar Using Quadratic Trend Method Based GIS International Journal of Engineering Technologies and Management Research, 170-180.

[16] Rusman. (2013). Model-Model Pembelajaran Mengembangkan Profesionalisme Guru. Jakarta: PT. Raja Grafindo Persada.

[17] Vaughan, T. (2006). Multmedia : Making It Work. Yogyakarta: Andi Offset.

[18] Wlliam W.Lee and Diana L.Owens. (2004). MultimediaBased Instructional Design. San Francisco: Pfeiffer.

[19] Prahasta Eddy. (2004). Sistem Informasi Geografis : Tools dan Plug-Ins. Bandung : Informatika Bandung

[20] Prahasta Eddy. (2005). Sistem Informasi Geografis : ArcView Lanjut. Bandung : Informatika Bandung

[21] FAO. 2011. E-learning Methodologies: A guide for designing and developing elearning courses. Rome: Food and Agriculture Organization of the United Nations.

[22] Frey, B.A. \& Sutton, J.M. 2010. A Model for Developing Multimedia Learning Projects. MERLOT Journal of Online Learning and Teaching; 6,2; 491-507. 